\title{
Comparative Analysis of Manual and Mechanised Yam Minisett Planting
}

\author{
A. K. Arkoh, S. K. Amponsah, J. Opoku Asante
}

\begin{abstract}
Drudgery has been identified as a critical area in the cultivation of yam. The aim of the study was to compare the manual and mechanised yam minisett planting. To address this problem, heart rate (HR) of workers during mounding and ridging, and planting were measured as well as assessing economic feasibility in mechanising yam planting. Polar watch (RS $800 \mathrm{CX}$ ) was used to measure HR of the operations. Hoe and cutlasses were used for mounding and ridging. The HR of tractor operator during planting was determined. Descriptive statistics and analysis of variance (ANOVA) were done using GenStat software (VSN International, 2011). Statistical significance was carried out at $p<0.05$. The field capacity was 3.84 and $1.45 \mathrm{~h} / \mathrm{ha}$ for mechanised and manual, respectively. The mean $H R$ was 112.80 and $112.7 \mathrm{bpm}$ for mounding and ridging respectively while 112.00, 132.00 bpm for mechanised and manual, respectively. Mechanised yam minisett planting reduces labour cost by $50 \%$.
\end{abstract}

Keywords: Drudgery, Manual, Mechanised, Planting, Yam Minisett.

\section{INTRODUCTION}

$\mathrm{T}$ he current trend of multiplying planting material of yam (minisett production) to plant large farm size within a shortest possible time requires the change of traditional planting method. Planting is process of buried of seed or planting material into the prepared seedbed. The traditional method of planting yam is painful and affects the yield according to [1]. Traditionally, mounding is by far the greatest common practice in Ghana and throughout the West African yam agro-ecology [3]. Mound forming is difficult and labour demanding that restricts yam production output [4]. Even though mounding is difficult, but [5] reported that the higher the mound or ridge, the greater the yield. It was stated by [6] that, a ridge height of $36 \mathrm{~cm}$ gives a greater yield. However, the ideal height of the ridge depends on the soil type and the cultivar grown. Also, a high broad mound and ridge are less washed away by rain. Although the drudgery involved in seedbed forming and planting is noticeable to be a problem [7], but researchers are silent in estimation of drudgery and economic viability during manual and mechanised planting

Manuscript received on August 29, 2021.

Revised Manuscript received on September 20, 2021.

Manuscript published on October 30, 2021.

*Correspondence Author

A. K. Arkoh*, Automotive and Refrigeration Engineering, Takoradi Technical University, Takoradi, Ghana. Emai: albert.arkoh@ttu.edu.gh

S. K. Amponsah, CSIR-Crops Research Institute, Kumasi, Ghana. Email: skamponsah@hotmail.com

J. Opoku-Asante, Agricultural and Biosystems Engineering, Kwame Nkrumah University of Science and Technology, Kumasi, Ghana Email: johnsonopokuasante@gmail.com

(c) The Authors. Published by Blue Eyes Intelligence Engineering and Sciences Publication (BEIESP). This is an open access article under the CC BY-NC-ND license (http://creativecommons.org/licenses/by-nc-nd/4.0/)

of yam minisett. Drudgery is difficulty in doing physical work. Drudgery could be measured through monitory of heart rate (HR) as a signal of workload. The use of HR is an active method of determining exercise oxygen agreement and energy expenditure for work done due to its solid connection with oxygen consumption [8],[9]. As [10] used HR to examine energy expenditure of oxen pulling an implement. An Individual's heart rate can also increase and drop just in response to answer, level of caffeine intake, ambient temperature, and health [11]. Several accounts on drudgery for physical activities were reported by [12],[10],[8].

The most serious restraint for growing yam production is the pain in planting procedure. Almost every stage of producing yam is labour-intensive, putting off the youth in the field of yam production which affects the scale of yam production. As [2], costs the stages involved in production such as clearing of the field, burning, and construction of seedbed to be about $49 \%$ of the labour expenditure to produce a hectare of harvested yam tubers in the rain forest agroecology of Nigeria. The manual planting rate according to [13] was 144 yam setts per hour this translated for 1152 setts for a farmer working at $8 \mathrm{~h}$ per day. According to [13]; [2]); about $50 \%$ of the expenditure of yam production go to the planting process against $40 \%$ of sweet potato [14]. Despite growing popularity in yam cultivation, there is no report on comparing HR in relation to seedbed forming (mounding and ridging) and planting (manual and mechanical) for yam cultivation.

The objectives of this study were to: (i) compare drudgery in seedbed forming (mounding and ridging) and planting (manual and mechanising) of yam minisett by determining the HR during these activities and (ii) to assess economic viability in mechanising yam planting. The study is hoped to estimate drudgery and cost-benefit in yam production in Ghana.

\section{METHODOLOGY}

\section{A. Study site}

The study site was Kwame Nkrumah University of Science and Technology (KNUST) Research Farm (Anwomaso) arable farm located $\left(6^{0} 41^{\prime} 56.75^{\prime} \mathrm{N}, 1^{0} 31^{\prime} 25.85^{\prime} \mathrm{W}\right)$, in the forest zone of the Ashanti Region. The map of Ghana at the study site was presented in Fig. 1. The study place experiences two rainy seasons (bi-modal rainfall), the main rain period starts from March to July and minor from September to November [12]. The soil classification at the study site was sandy loam and soils were predominantly Forest Ochrosols, while mean annual rainfall and relative humidity were $1200 \mathrm{~mm}$ and $72.8 \%$ respectively. Temperature also ranges from 20 to $32{ }^{\circ} \mathrm{C}$ [15].

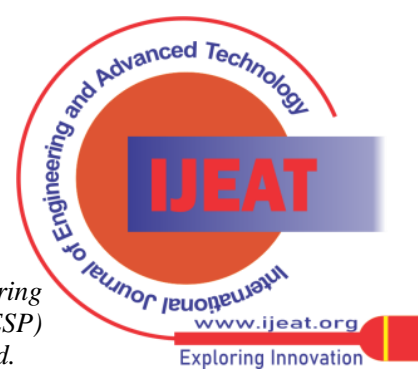




\section{Comparative Analysis of Manual and Mechanised Yam Minisett Planting}

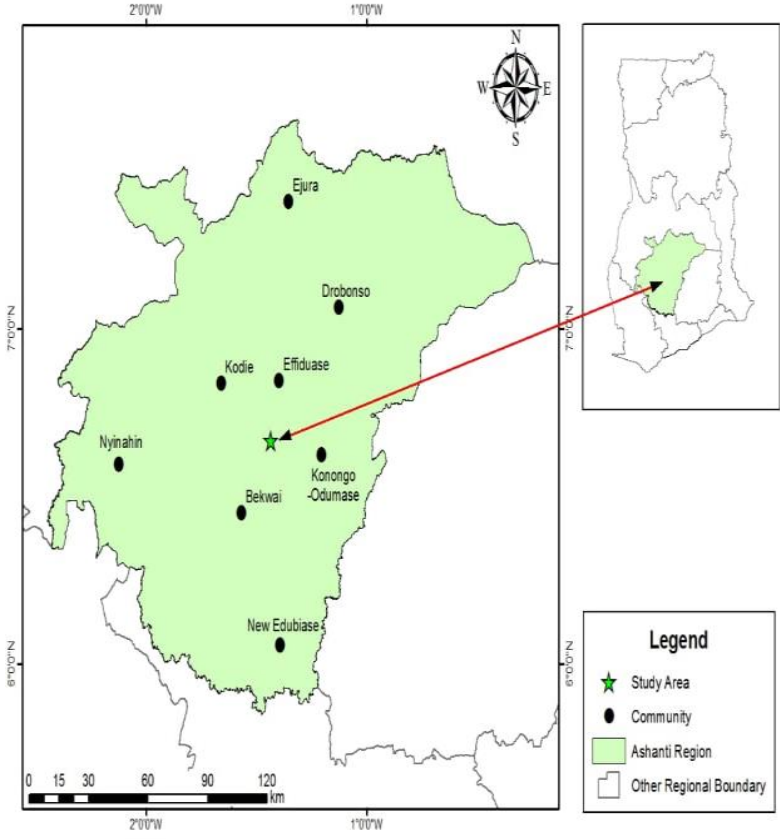

Fig. 1: Map showing the study site

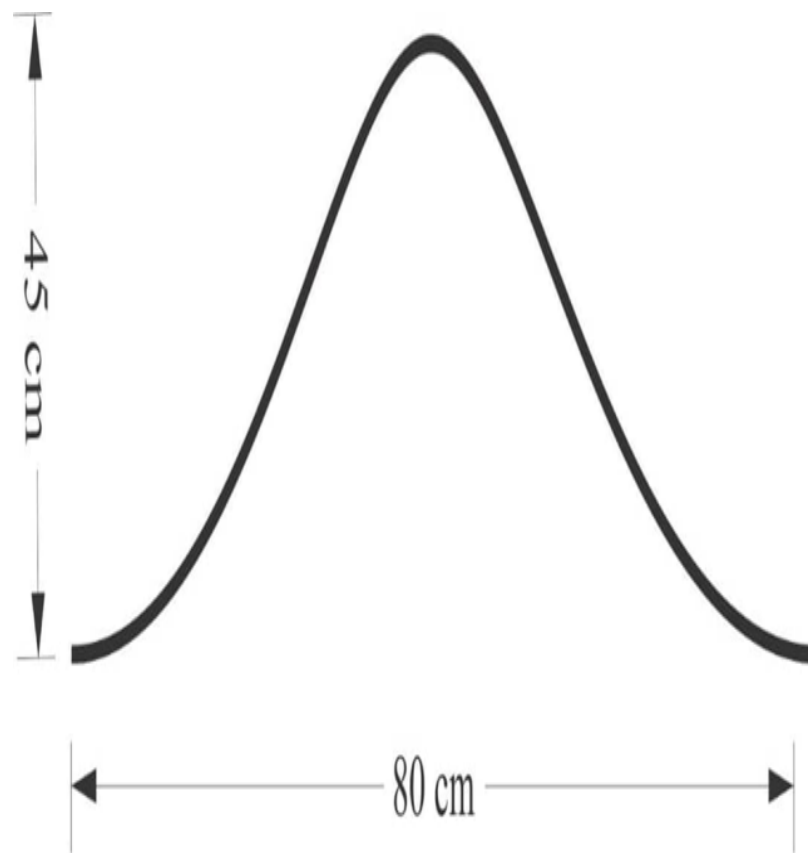

Fig. 2a. mound seedbed

\section{Heart Rate Measurement}

The HR of the workers were determined to predict the energy expenditure whiles time was recorded to establish the duration for each operation to determine HR of every activity. The mean HR for respective planting operations were determined using Polar watch (RS $800 \mathrm{CX}$ ). The strap was worn around the chest of the workers for $20 \mathrm{~min}$ before seedbed forming operations started and rest 25 min after the operation ended. Because mounting of the sensor brings stress, workers were given $20 \mathrm{~min}$ to rest after sensor

\section{B. Land Preparation}

Mounding and ridging were done on $2^{\text {nd }}$ March 2019 using hoes and cutlasses after the land was ploughed and harrowed by gathering topsoil to form conical (mound) heaps $45 \mathrm{~cm}$ high and $100 \mathrm{~cm}$ base. Between plants was 1 x $1 \mathrm{~m}$ apart from crest to crest. Ridges were constructed the same size as a mound to be $10 \mathrm{~m}$ long to contain the same number of plants (225) as mounds. Male workers of average age of 47, height $1.62 \mathrm{~m}$ and average weight (body mass) of $64 \mathrm{~kg}$ were hired for mound preparation and planting (minisett burying). The average weight of the workers before and after mounding and ridging were taken separately to determine weight lost during seedbed preparation and planting because Smith et al. (1994) related weight lost to energy spent during physical activities. The weights of the workers were taken before and after every activity. The shape and the size of the mound and ridge seedbed were presented in Fig. 2 (a) and (b). The mound (45 $\mathrm{cm}$ height and $80 \mathrm{~cm}$ base was in Fig. 2b whereas ridge, 45 $\mathrm{cm}$ height and $80 \mathrm{~cm}$ base) was in Fig. 2b. The rate of mounding and ridging was obtained by dividing the number of mounds or ridges formed by the time taken. The height and weights of the workers were measured using steel tape measurement and weighing scale.

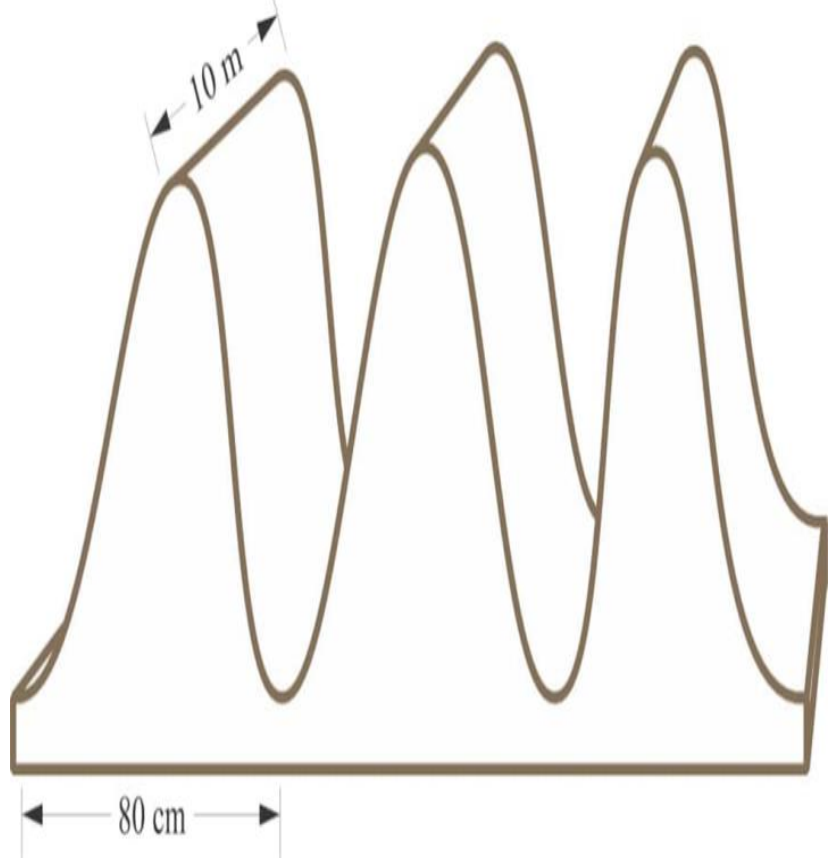

Fig. 2b. ridge seedbed

attachment. HR data were set concurrently at a sample rate of 5 s pauses [10]. The same procedure was used for planting. How polar watch with heart beat sensor attachment was worn before working activity was presented in Fig. 3 . The rate of raising mounds and ridging was also determined by the same procedure and technology. How much energy was spent to carry out during work is important in calculate the rest period $(\mathrm{min} / \mathrm{h})$ needed by a person after working activities equation (1) [16].

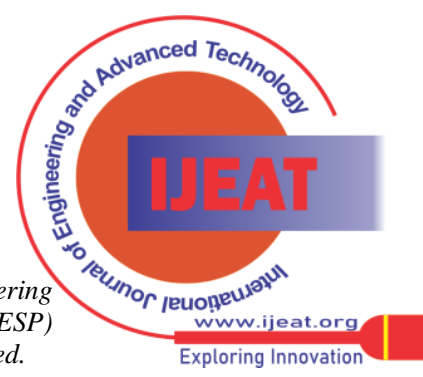



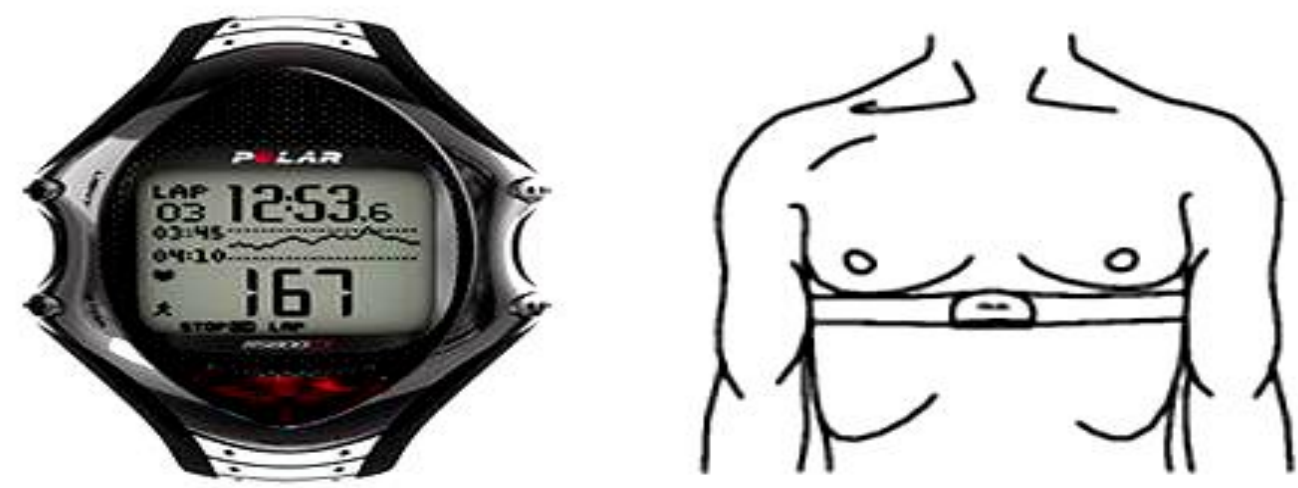

Fig. 3: Polar (RS $800 \mathrm{CX})$ watch and chest strap as worn by a person

Source: [12]; [10].

$\operatorname{Tr}=60\left(1-\frac{250}{p}\right)$

where,

$\operatorname{Tr}=$ Total rest period $(\mathrm{min} / \mathrm{h})$

$P=$ Gross energy consumption (Watts)

Heart rate energy conversion chart was used to convert the mean heart rate attained for an activity to determined equivalent energy consumption [12].

\section{Manual Planting Capacity}

Yam (pona) tubers that have broken dormancy were acquired from Crop Research Institute (CRI) Kumasi, Ghana. The tuber was sliced into minisett weighing an average of 50 g with moisture content of $82 \%$. The sliced setts surfaces were spread out in open space and then allowed to dry for an hour. Ashes were applied on the surfaces before planting to avoid rotten [17]. The same male workers who constructed the seedbed were tasked after two weeks to plant 225 yam minisett on mound, ridge, and flat, while time used during planting was recorded for the individual workers. Planting started at the beginning of rain on $20^{\text {th }}$ April 2016 in order to moist the seedbed. The setts were buried to an average depth of $12.5 \mathrm{~cm}$ from the apex of mound or ridge using hoes and cutlasses. Planting capacity (sett/h) was determined using equation (2) adopted from [18]. Timing of seedbed forming and planting activities were taken using a stopwatch, meanwhile, the height and weights of the workers were measured using $30 \mathrm{~m}$ steel tape measure and weighing scale.

$$
\text { Plowting capacity }=\frac{\text { winisett planted } X 36}{10000 \mathrm{X} \text { time taken (s) }}
$$

\section{E. Planter Economic Feasibility Assessment}

The costs of planting with a double row mechanised yam minisett planter were calculated using the assumptions in Table 1 according to [12],[19].

Table 1. Assumptions and recommendations for cost calculations

\begin{tabular}{ll}
\hline Cost Parameter & Assumptions \\
\hline Salvage value & 0.0 \\
Insurance & $0.5 \%$ of the purchasing price \\
Shelter & $0.5 \%$ of the purchasing price \\
Interest & $0.5 \%$ of the purchasing price \\
Taxes & $0 \%$ of purchasing price* \\
Lubricant cost & $15 \%$ of fuel cost \\
Hectare planted/year & 100 \\
\hline
\end{tabular}

*Though, agricultural inputs are tax-free by law but subject to current law. If the law is changed, that may also change.

Depreciation and interest on planter ownership were determined using equation (3) and (4) respectively [20].

$$
\text { Depreciation }=\frac{\text { Purchase price }- \text { Salwage walue }}{\text { Economic life }}
$$

The expected revenue, profit, and breakeven cost were determined for each planting method adopted by [2] using equation 5.

$$
\text { Breakeven }=\frac{\text { Total fixed cost }}{\text { Hiring cost }- \text { total wariable cost }}
$$

\section{F. Data Analysis}

Descriptive statistics and analysis of variance (ANOVA) were done using GenStat software (VSN International, 2011). Means were obtained using the least significant difference (LSD) when the treatment effect is significant at $\mathrm{p}$ $\leq$ 0.05. Tukey and Fisher's approach was used to determine differences in treatment mean.

\section{RESULTS AND DISCUSSION}

\section{A. Land Preparation and Planting}

Table 1 presents seedbed preparation and manual planting capacity, time taken for seedbed preparation and planting as well. A worker took an hour to construct 35 mounds and $1 \mathrm{~h}$ for 6 ridges of $6.2 \mathrm{~m}$ long. On the basis of seedbed preparation rate, 284 and 258 man-hours were required for mounding and ridging respectively. The seedbed type could contribute to the differences in mounding and ridging time. Again, 2.5, 2.5, and $3.2 \mathrm{~h}$ were used for planting (sett burying) 225 setts on mound, ridge, and flat, respectively. The planting rate was 90,90 , and 71 sett/h for mound, ridge, and flat, respectively. The average time per hectare for sett burying alone were 142,111 , and $111 \mathrm{~h} / \mathrm{ha}$ for flat, ridge, and mound, respectively. Time taken for seedbed preparation and burying of sett for hectare were 142, 396 and $369 \mathrm{~h} / \mathrm{ha}$ (man-hour) for flat, mound and ridge, respectively. More time was used for flat planting.

Published By:

Blue Eyes Intelligence Engineering and Sciences Publication (BEIESP) (C) Copyright: All rights reserved.

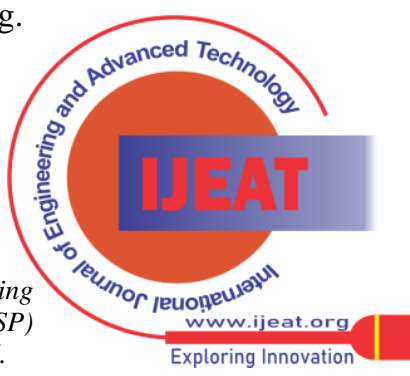




\section{Comparative Analysis of Manual and Mechanised Yam Minisett Planting}

Meanwhile, additional time for mounding and ridging together with burying could also play a role in the difference in planting capacity per hectare. Again, seedbed type played a role in the difference in planting rate. The result showed that as result of pegging before planting on flat seedbed, planting on flat seedbed would plant fewer plants than planting on mound and ridge. This result disagrees with the study by [2] that ridging as seedbed for yam cultivation costs higher than planting on flat if time is quantified into money. This means that, additional time for pegging made costs of cultivating on the flat seedbed more than that of ridging. Average planting rate would mean that a worker would need 8 man-hours to plant an average of 669 setts, translating 0.066 ha/day.

Table 2: Seedbed preparation and manual planting rate

\begin{tabular}{lllllll}
\hline Location & $\begin{array}{l}\text { Seedbed } \\
\text { Type }\end{array}$ & $\begin{array}{l}\text { No. of } \\
\text { seedbed }\end{array}$ & $\begin{array}{l}\text { Duration for land } \\
\text { forming }(\mathrm{h})\end{array}$ & $\begin{array}{l}\text { Seedbed forming } \\
\text { rate/h }\end{array}$ & $\begin{array}{l}\text { No. sett } \\
\text { planted }\end{array}$ & $\begin{array}{l}\text { Planting time } \\
\text { (h) }\end{array}$ \\
\hline UCCRF & Mound & 225 & 6.4 & 35 & 225 & 2.5 \\
& Ridge & 36 & 5.8 & $6(6.2 \mathrm{~m})$ & 225 & 2.5 \\
& Flat & 1 & - & - & 225 & 3.2 \\
(sett/h)
\end{tabular}

\section{B. Heart Rate Measurement}

Table 2 illustrates the mean HR with matching gross energy consumed and rest period during seedbed-forming (mounding, ridging) and planting activities. The mean heart rates during mounding and ridging were 112.80 and 112.70 bpm, respectively. Similarly, the energy expenditure needed for mounding was $665.15 \mathrm{~W}$ and ridging $664.56 \mathrm{~W}$. There was no significant difference ( $>00.05)$ in mean heart rate for mounding and ridging. Similarly, the mean heart rate at manual and mechanical planting was 132.00 and $112.00 \mathrm{bpm}$, respectively. Again, the energy needed for manual and mechanical was 886.26 and $660.04 \mathrm{~W}$, respectively. There were significant $(p \geq 0.05)$ differences between the mean heart rate for manual and mechanised planting. It was observed that the mean heart rate, gross energy consumption, and rest periods could mean that the longer period of rest was needed to compensate for used energy. The association among energy consumption and the rest period were in line with findings by [12]; [10] that, physical work requires more rest periods.

Table 3: Mean heart rate (bpm), gross energy consumption $(\mathrm{W})$ and total rest period $(\mathrm{min} / \mathrm{h})$ for seedbed-forming and manual planting

\begin{tabular}{llll}
\hline & Evaluation parameter & & \\
\hline Activities & Mean Heart Rate $(\mathrm{bpm})$ & Estimated Energy $(\mathrm{W})$ & Rest Period $(\min / \mathrm{h})$ \\
\hline Manual Planting & $132.00_{\mathrm{a}}$ & 886.26 & 43.07 \\
Mechanised planting & $112.00_{\mathrm{b}}$ & 660.04 & 37.27 \\
\hline LSD & 11.36 & & 37.43 \\
\hline Ridging & 112.70 & 664.56 & 37.45 \\
\hline Mounding & 112.80 & 665.15 & - \\
\hline
\end{tabular}

Within each column, means followed by the same subscript letter are significantly different at $\mathrm{p} \leq 0.05$

Heart rate profiles during manual and mechanised yam minisett planting were presented in Fig. (4a) and (b). The HR profile during manual was Fig. 4a, whereas HR profile during mechanised planting was in Fig. 4b. The profile describes rest before work, planting and recovery after work.
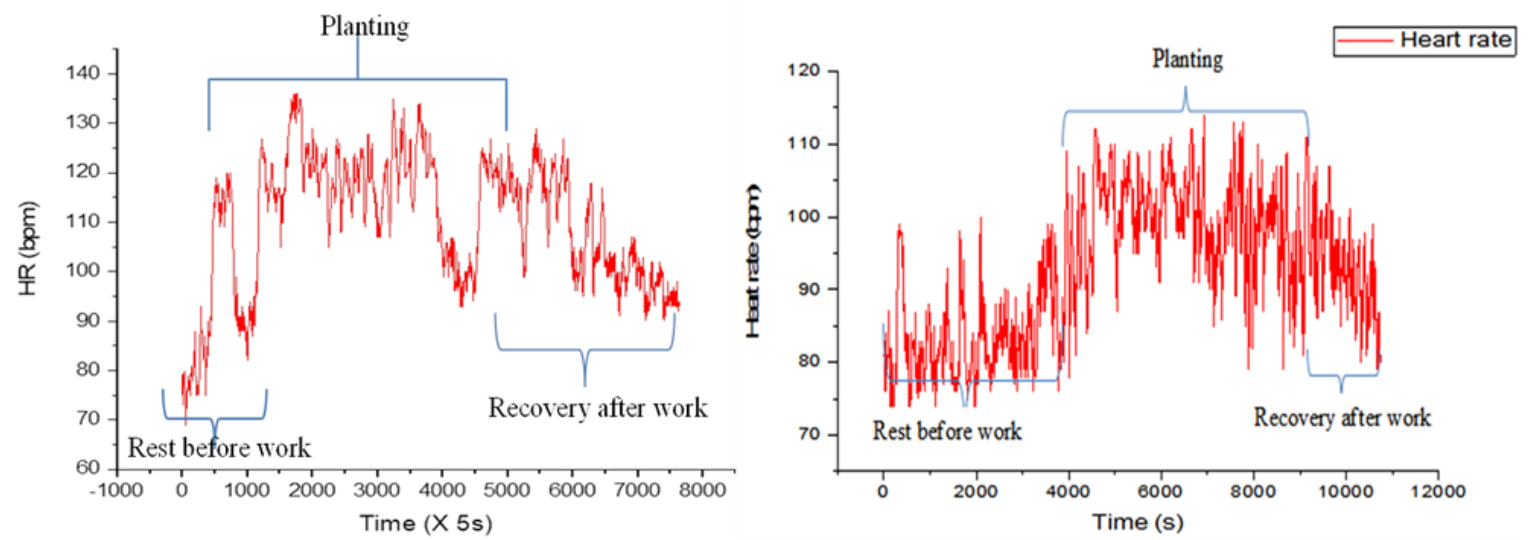

Fig. 4a. Heart rate profile during manual, 4b); mechanised yam minisett planting 


\section{Economic Analysis of the Planter}

Table 3 and 4 presents the cost per hector for using manual and mechanised planting, respectively. It could be observed from the table that planting with the DRYM planter allows a reduction of $50 \%$ labour cost for planting and increasing timeliness in planting of $75 \%$. This is similar to findings by [13] that the use of a mechanical planter reduces the total cost of yam production. Again, investing in the DRYM planter of Gh $\mathbb{3} 3400.00$, the mechanised yam planting offered a total annual cost of $\mathrm{Gh} \not \mathbf{5} 511.00$.

Table 4: Manual planting cost

\begin{tabular}{llllllll}
\hline $\begin{array}{l}\text { Seedbed-form } \\
\text { type }\end{array}$ & $\begin{array}{l}\text { Seedbed-form } \\
\text { unit }\end{array}$ & $\begin{array}{l}\text { Unit cost } \\
(\mathrm{GH})\end{array}$ & $\begin{array}{l}\text { Total cost } \\
(\mathrm{Gh})\end{array}$ & $\begin{array}{l}\text { Number of } \\
\text { plants }\end{array}$ & Unit cost & $\begin{array}{l}\text { Total } \\
\text { cost }\end{array}$ & $\begin{array}{l}\text { Cost per hectare } \\
(\mathrm{Gh} / \mathrm{ha})\end{array}$ \\
\hline Mound & 224 & 0.5 & 112 & 224 & 0.2 & 44.8 & 14,000 \\
Ridges & 36 & 4 & 108 & 224 & 0.2 & 44.8 & 13,650 \\
Flat & - & - & - & 228 & 0.4 & 91.2 & 8,000 \\
\hline
\end{tabular}

The total costs of manual yam planting per hectare on a different seed-form (mound, ridges, and flat) were

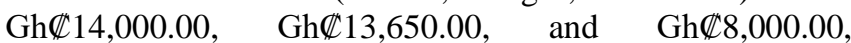
respectively as shown in Table 4 for the study site. Apart from several benefits in using mechanical yam planter, so far as the work is completed at an appreciable reduction labour cost and within a shorter time as compared to manual planting makes it easier for the farmer to cultivation at the right time. This increases the timeliness of fieldwork. Furthermore, using yam planter helps to reduce deficiencies in planting processes such as uniformity of plant spacing, plant depth, covering procedure, etc. Meanwhile, the total cost of yam planting under ridges was higher, followed by mound and flat, which was contrary to estimation by [19] that, yam production on ridge cost less than using mound.

Table 5: Planter cost estimation

\begin{tabular}{|c|c|}
\hline Cost Parameter & Costs $(\mathrm{Gh} \not \mathbf{C})$ \\
\hline Purchase price & 3400.00 \\
\hline Salvage value & 0 \\
\hline Economic life (year) & 10 \\
\hline Fixed Costs & $(\mathrm{Gh} \mathbb{C} / \mathbf{y})$ \\
\hline Depreciation & 340.00 \\
\hline Interest & 17.00 \\
\hline Insurance & 17.00 \\
\hline Tax & 0.00 \\
\hline Shelter & 17.00 \\
\hline Total Fixed Cost & 391.00 \\
\hline Fuel (diesel) cost $(\mathrm{Gh} \mathbb{C} / \mathrm{L})$ & 4.80 \\
\hline Fuel Consumption (average) (L/ha) & 9.2 \\
\hline Field Capacity (average) & 0.26 \\
\hline Hectare cultivated (ha/y) & 100 \\
\hline Labour Cost (GhÆ/ha) & 20.00 \\
\hline Number of labourers & 1 \\
\hline Variable Cost & $(\mathrm{Gh} \mathbb{C} / \mathrm{h})$ \\
\hline Fuel & 11.48 \\
\hline Lubricant & 1.72 \\
\hline Repair and Maintenance $(\mathrm{Gh} \mathbb{C} / \mathrm{ha})$ & 17.00 \\
\hline Labour & 20.00 \\
\hline Total cost $(\mathrm{Gh} \mathbb{C} / \mathrm{h})$ & 50.20 \\
\hline Total Variable Cost & 5020.00 \\
\hline Total Cost $(\mathrm{Gh} \mathbb{C} / \mathrm{y})$ & 5411.00 \\
\hline
\end{tabular}

The breakeven analysis chart for using the DRYM planter was presented in Fig. 5. The breakeven point for the yam minisett planter was $4.5 \mathrm{y}$ of machine use, equivalent to approximately 117 ha of yam field planted. This result shows that using a double row mechanical yam sett planter seasonally, the investment would be better with the substantial profit made through routine hiring of the planter.

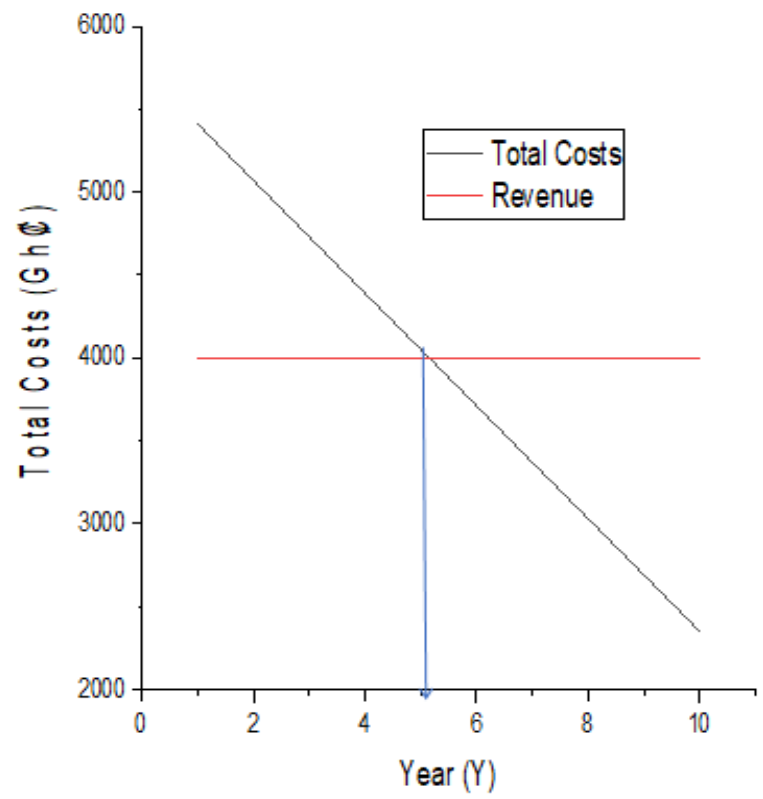

Fig. 5. Breakeven analysis of using a mechanical planter

\section{CONCLUSION}

1. Deploying mechanical yam minisett planter had demonstrated much better reduction in total planting cost by about $50 \%$, and $75 \%$ timeliness increase over manual planting option

2. The heart rates for manual and mechanised planting were 132.00 and $112.00 \mathrm{bpm}$, respectively. There was significant $(\mathrm{p}<0.05)$ difference between the mean heart rate for manual and mechanised planting and the same translated into rest period of $43.07 \mathrm{~m} / \mathrm{h}$ for manual and $37.32 \mathrm{~m} / \mathrm{h}$ for mechanised planting.

\section{ACKNOWLEDGMENT}

The authors wish to express their profound gratitude to Mr. Benjamin Assaga of KNUST and the entire staff of Takoradi Technical University, Department of Auto and Ref. Engineering.

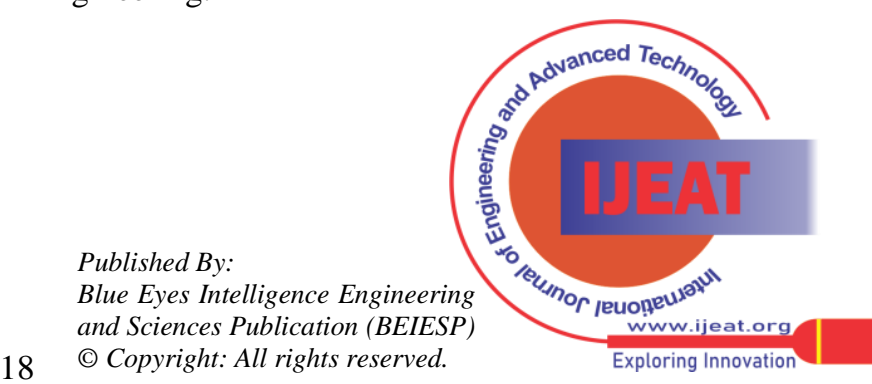




\section{Comparative Analysis of Manual and Mechanised Yam Minisett Planting}

\section{REFERENCES}

1. M.G. Boydas. Effect of cup size, seed characteristics and Angular speed on the performance of an automatic potato planter under laboratory condition. Journal of agricultural sciences 23. 317-327, 2017.

2. S. Ennin, E. Otoo and F. Tetteh. Ridging, a mechanized alternative to mounding for yam and cassava production. West African Journal of Applied Ecology, 15. 1-8, 2009.

3. D. Coursey. Bilateral bargaining, Pareto optimality, and the empirical frequency of impasse. Journal of Economic Behavior \& Organization, 3, 243-259, 1967.

4. H. C. Ezumah. Important Root Crops Production Systems in Southern Nigeria. Paper presented at Seminar on Nigerian Root Culture at the Institute of African Studies. University of Ibadan, Nigeria, 1986.

5. K. J. Brobbey, J. Haapanen, M. Gunell, J. M. Mäkelä, E. Eerola, M. Toivakka and J. J. Saarinen. One-step flame synthesis of silver nanoparticles for roll-to-roll production of antibacterial paper. Applied Surface Science, 420, 558-565, 2017.

6. A. Q. Villordon, D. R. La Bonte, N. Firon, Y. Kfir, E. Pressman and A. Schwartz. Characterization of adventitious root development in sweet potato. HortScience, 44, 651-655, 2009.

7. S. Ennin, H. Dapaah and J. Asafu-Agyei. Land preparation for increased sweet potato production in Ghana. Tropical Root and Tuber Crops• Opportunities for Poverty Alleviation and Sustainable Livelihoods in Developin4 Countries: Proceedings of the Thirteenth Triennial Symposium of the International Society for Tropical Root Crops, 227-232, 2014.

8. F. Ericsson, U. Dalarna and G. Björklund. The relationship between heart rate and power output during cycling competitions.Available online:http://www.toppfysik.nu/userfile/The\%20relatioship\%20heart \%20rate\%20and\%20power\%20output\%20during\%20road\%20cyclin g\%20competitions.pdf.Date accessed: 14-11-2018.

9. S. Crouter, C. Albright and D. Bassett. Accuracy Of The Polar S410 Heart Rate Monitor For Estimating The Energy Cost of Exercise. Medicine \& Science in Sports \& Exercise, 36, 2004.

10. E. Y. H. Bobobee and G. Gebresenbet. Effect of cutting thickness and state of ploughshare on draught force and heart rates of Sanga oxen in Ghana. Soil \& Tillage Research. 95, 298-307, 2007.

11. H. Montoye. Measuring physical activity and energy expenditure. Champaign. Human Kinetics, IL, 1996.

12. S. K. Amponsah, E. Y. H. Bobobee, W. A. Agyare, J. B. Okyere, J. Aveyire., S. R. King and J. Sarkodie-Addo. Mechanical cassava harvesting as influenced by seedbed preparation and cassava variety. Applied Engineering in Agriculture, 30, (3), 391-403, 2014.

13. J. Awulu, J. Audu and G. Nuhu. Development and Evaluation of Manually Operated Seed Broadcaster. Journal of Agricultural Engineering and Biotechnology, 2, 13, 2014.

14. C. Stoddard, K. Klonsky and R. Demoura. Sample costs to produce sweet potatoes. Univ. California Coop. Ext. PO-SJ-06, 2006.

15. D. W. Smith, B. G. Sims and D. H. O'Neill.Testing and Evaluation of Agricultural Machinery and Equipment: Principles and Practices. Rome, Italy: Food and Agriculture Organization, 1994

16. N. Jones. The interpretation of stage 1 exercise test results. Clinical exercise testing, 158, 1988.

17. O. Ovono, C. Kevers and J. Dommes. Effects of planting methods and tuber weights on growth and yield of yam cultivars (Dioscorea rotundata Poir.) in Gabon. International Research Journal of Agricultural Science and soil Science, 6, 32-42, 2016.

18. J. Awulu, I. Itodo and V. Umogbai, V. Effect of Tractor Forward Speed on Metering Efficiency and Evenness of Planting of a Device for Mechanized Yam Sett Planting. The International Journal of Engineering and Science (IJES),2(5), 61-67, 2013.

19. C. K. Bosrotsi, A. Addo, K. A. Dzisi and S. K. Agodzo, S. Technical Performance and Economic Feasibility Assessment of A Mechanical Yam Harvester. International Journal of Research Studies in Agricultural Sciences (IJRSAS), 3 (3), 1-8, 2017b.

20. K. Hunt. Structural kinematics of in-parallel-actuated robot-arms.Journal of Mechanisms, Transmissions, and Automation in Design, 105, 705-712, 1983.

\section{AUTHORS PROFILE}

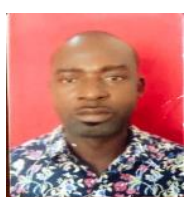

A. K. Arkoh (Ph. D), from Kwame Nkrumah University of Science and Technology (KNUST) Kumasi, Ghana, Department of Agricultural and Biosystems Engineering and currently lecture at Takoradi Technical University, Department of Automotive and Refrigeration.

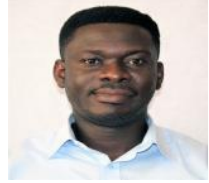

S. K. Amponsah (Ph.D) from Kwame Nkrumah University of Science and Technology (KNUST) Kumasi, Ghana, Department of Agricultural and Biosystems Engineering and currently works at CSIR-Crops Research Institute, Kumasi, Ghana

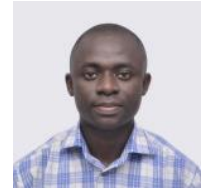

J. Opoku-Asante (MSc), from Kwame Nkrumah University of Science and Technology (KNUST) Kumasi, Ghana, Department of Agricultural and Biosystems Engineering and currently works at KNUST, Kumasi.

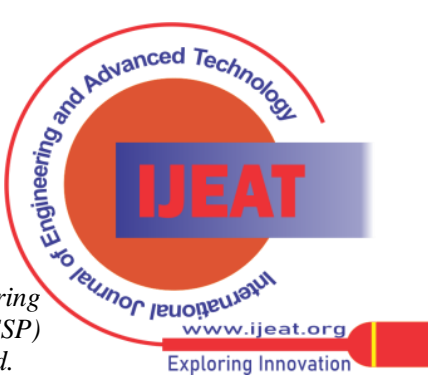

